\title{
Expert assessment of vulnerability of permafrost carbon to climate change
}

\author{
E. A. G. Schuur • B. W. Abbott • W. B. Bowden • \\ V. Brovkin • P. Camill • J. G. Canadell • J. P. Chanton • \\ F. S. Chapin III • T. R. Christensen • P. Ciais • \\ B. T. Crosby • C. I. Czimczik • G. Grosse • J. Harden • \\ D. J. Hayes • G. Hugelius • J. D. Jastrow • J. B. Jones • \\ T. Kleinen • C. D. Koven • G. Krinner • P. Kuhry • \\ D. M. Lawrence • A. D. McGuire • S. M. Natali • \\ J. A. O'Donnell • C. L. Ping • W. J. Riley • A. Rinke • \\ V. E. Romanovsky • A. B. K. Sannel • C. Schädel • \\ K. Schaefer • J. Sky • Z. M. Subin • C. Tarnocai • \\ M. R. Turetsky • M. P. Waldrop • K. M. Walter Anthony • \\ K. P. Wickland • C. J. Wilson • S. A. Zimov
}

\begin{abstract}
Approximately 1700 Pg of soil carbon (C) are stored in the northern circumpolar permafrost zone, more than twice as much $\mathrm{C}$ than in the atmosphere. The overall amount, rate, and form of $\mathrm{C}$ released to the atmosphere in a warmer world will influence the strength
\end{abstract}

Electronic supplementary material The online version of this article (doi:10.1007/s10584-013-0730-7) contains supplementary material, which is available to authorized users.

E. A. G. Schuur and B. W. Abbott contributed equally to this publication

E. A. G. Schuur $(\square) \cdot$ S. M. Natali $\cdot$ C. Schädel

University of Florida, Gainesville, FL, USA

e-mail: tschuur@ufl.edu

B. W. Abbott • F. S. Chapin III • G. Grosse · J. B. Jones • C. L. Ping • V. E. Romanovsky •

K. M. Walter Anthony

University of Alaska Fairbanks, Fairbanks, AK, USA

W. B. Bowden

University of Vermont, Burlington, VT, USA

V. Brovkin - T. Kleinen

Max Planck Institute for Meteorology, Hamburg, Germany

P. Camill

Bowdoin College, Brunswick, ME, USA

J. G. Canadell

Global Carbon Project CSIRO Marine and Atmospheric Research, Canberra, Australia 
of the permafrost $\mathrm{C}$ feedback to climate change. We used a survey to quantify variability in the perception of the vulnerability of permafrost $\mathrm{C}$ to climate change. Experts were asked to provide quantitative estimates of permafrost change in response to four scenarios of warming. For the highest warming scenario ( $\mathrm{RCP} 8.5$ ), experts hypothesized that $\mathrm{C}$ release from permafrost zone soils could be 19-45 Pg C by 2040, 162-288 Pg C by 2100, and 381-616 Pg C by 2300 in $\mathrm{CO}_{2}$ equivalent using 100-year $\mathrm{CH}_{4}$ global warming potential (GWP). These values become $50 \%$ larger using 20 -year $\mathrm{CH}_{4} \mathrm{GWP}$, with a third to a half of expected climate forcing coming from $\mathrm{CH}_{4}$ even though $\mathrm{CH}_{4}$ was only $2.3 \%$ of the expected $\mathrm{C}$ release. Experts projected that twothirds of this release could be avoided under the lowest warming scenario (RCP 2.6). These results highlight the potential risk from permafrost thaw and serve to frame a hypothesis about the magnitude of this feedback to climate change. However, the level of emissions proposed here are unlikely to overshadow the impact of fossil fuel burning, which will continue to be the main source of $\mathrm{C}$ emissions and climate forcing.

$\begin{array}{ll}\text { Abbreviations } \\ \mathrm{Pg} & \text { Petagrams } \\ \mathrm{C} & \text { Carbon } \\ \mathrm{CO}_{2} & \text { Carbon dioxide } \\ \mathrm{CH}_{4} & \text { Methane } \\ \mathrm{RCP} & \text { Representative concentration pathway } \\ \mathrm{GWP} & \text { Global warming potential }\end{array}$

\section{Introduction}

Recent scientific studies estimate that soils of the northern permafrost zone contain almost 1700 Petagrams (Pg) of organic carbon (C) (Tarnocai et al. 2009; Schuur et al. 2008), much more than previously recognized (Jobbagy and Jackson 2000; Gorham 1991). In part, this new insight was a

J. P. Chanton

Florida State University, Tallahassee, FL, USA

T. R. Christensen

Lund University, Lund, Sweden

P. Ciais

LSCE, CEA-CNRS-UVSQ, Gif-sur-Yvette, France

B. T. Crosby

Idaho State University, Pocatello, ID, USA

C. I. Czimczik

University of California, Irvine, CA, USA

J. Harden

US Geological Survey, Menlo Park, CA, USA

D. J. Hayes · M. P. Waldrop

Oak Ridge National Laboratory, Oak Ridge, TN, USA

G. Hugelius • P. Kuhry • A. B. K. Sannel

Stockholm University, Stockholm, Sweden 
result of $\mathrm{C}$ measurements much deeper in permafrost - perennially frozen soils stored as a result of processes unique to frozen soils. Freeze-thaw mixing in combination with wind- and waterborne sediment deposition over hundreds and thousands of years has buried $\mathrm{C}$ many meters deep into permafrost soils, much deeper than had been traditionally accounted for by soil C inventories (Ping et al. 2010). The so-called permafrost carbon inventory considers the entire soil organic $\mathrm{C}$ stock including organic soils, mineral soils, peatlands, and soils above the surface of permafrost (active layer) that thaw seasonally. The top $3 \mathrm{~m}$ of all permafrost-zone soils contain $1024 \mathrm{Pg} \mathrm{C}$, with $818 \mathrm{Pg}$ of that contained in the actual Gelisol soil order (permafrost-affected soils). The remaining fraction is in other soil orders within the northern circumpolar permafrost zone, because only some ground is underlain by permafrost in the discontinuous and sporadic/isolated zone. In sum, permafrost-affected soils contain $88 \%$ of the total $1672 \mathrm{Pg} \mathrm{C}$ found in the northern circumpolar permafrost zone, when also accounting for the $648 \mathrm{Pg}$ of deep permafrost $\mathrm{C}(>3 \mathrm{~m})$ in Siberia, Alaska, and the Arctic river deltas (Zimov et al. 2006; Tarnocai et al. 2009). The uncertainty of this stock estimate is at present unknown but could be on the order of several hundred Pg (McGuire et al. 2010), and the estimate will continue to be revised as additional data from these remote places becomes available (Schirrmeister et al. 2011; Johnson et al. 2011; Kanevskiy et al. 2011). This $\mathrm{C}$ accumulated over thousands of years under cold and sometimes waterlogged conditions, but these very factors that protect and retain organic $\mathrm{C}$ in northern soils are now changing as the climate warms.

In the Arctic, temperatures are rising ultimately as a result of greenhouse gas emissions primarily from fossil fuel burning, deforestation, and other human activities elsewhere on Earth. The magnitude of future temperature rise depends on the trajectory of human emissions in combination with the response of the Earth system to this forcing. Models agree that Arctic warming will be greater than average global warming, with some models projecting a $7-8{ }^{\circ} \mathrm{C}$ warming over land in these regions by the end of the 21 st century under the A2 emissions scenario (ACIA 2005; Meehl et al. 2007). For such high-warming scenarios, models project there will be large reductions in near-surface (top 2-3 m) permafrost by 2100 , with some estimates ranging from $53 \%$ to $66 \%$ decrease from current areal extent (Euskirchen et al. 2006; Saito et al. 2007; Lawrence et al. 2011). Thawing of frozen

J. D. Jastrow

Argonne National Laboratory, Argonne, IL, USA

C. D. Koven • W. J. Riley $\cdot$ Z. M. Subin

Lawrence Berkeley National Lab, Berkeley, CA, USA

G. Krinner

CNRS/UJF-Grenoble 1, LGGE, Grenoble, France

D. M. Lawrence

National Center for Atmospheric Research, Boulder, CO, USA

A. D. McGuire

U.S. Geological Survey, Alaska Cooperative Fish and Wildlife

Research Unit, University of Alaska,

Fairbanks, AK, USA

J. A. O'Donnell

Arctic Network, National Park Service, Fairbanks, AK, USA

A. Rinke

Alfred Wegener Institute, Potsdam, Germany 
ground, which is already underway (Romanovsky et al. 2011), has the potential to influence the future storage of permafrost C. Because the permafrost $\mathrm{C}$ pool is so large, release of even a fraction of this $\mathrm{C}$ into the atmosphere could accelerate the pace of climate warming.

How $\mathrm{C}$ emissions from the permafrost zone will influence the future pace of climate change can be framed by three key questions (Schuur et al. 2008). First, how much permafrost $\mathrm{C}$ is vulnerable to release into the atmosphere? As these soils thaw, ancient $\mathrm{C}$ is available for decomposition by soil organisms and is released to the atmosphere as greenhouse gases. Some of this $\mathrm{C}$ is easily metabolized and will be consumed quickly by microorganisms while other fractions are more difficult to break down because of chemical or physical recalcitrance of the organic matter and may remain within the soil for much longer. This mixture of $\mathrm{C}$ also dictates the second key question: how fast will this $\mathrm{C}$ release occur? Rapidly decomposing $\mathrm{C}$ can be released on timescales of less than one year after thaw, but this represents a few percent of the permafrost $C$ pool (Zimov et al. 2006; Dutta et al. 2006). The bulk of permafrost $C$ is likely to be released slowly over decades after thaw with a small proportion of $\mathrm{C}$ persisting within the soil for much longer (Fan et al. 2008). Finally, the third key question is: what will be the form of this $\mathrm{C}$ release? Whether soil microorganisms release carbon dioxide $\left(\mathrm{CO}_{2}\right)$ or methane $\left(\mathrm{CH}_{4}\right)$ will determine the ultimate radiative-forcing potential of these emissions. Methane is produced in waterlogged lowoxygen environments common in the Arctic and has around 33 times the global warming potential of $\mathrm{CO}_{2}$ over a century time scale (Shindell et al. 2009). However, waterlogged environments that favor $\mathrm{CH}_{4}$ release also slow overall emission rates and retain higher amounts of $\mathrm{C}$ within soil. It is the balance between these two opposing factors as well as the overall distribution of upland (oxic) and lowland (anoxic) environments across the Arctic landscape that will determine the ratio of $\mathrm{CO}_{2}$ to $\mathrm{CH}_{4}$ emissions.

Aside from biological decomposition, fire could be an important abiotic mechanism for releasing permafrost $\mathrm{C}$ to the atmosphere. Fire frequency and severity are increasing in some parts of the boreal permafrost zone (Turetsky et al. 2011), and rare events such as the large Alaskan tundra wildfire in 2007 (Mack et al. 2011) may become more common in the future. Fires release $\mathrm{C}$ directly to the atmosphere via combustion and also indirectly by warming

K. Schaefer

National Snow and Ice Data Center, Cooperative Institute for Research in Environmental Sciences, University of Colorado, Boulder, CO, USA

J. Sky

University of Oxford, Oxford, UK

C. Tarnocai

AgriFoods, Ottawa, ON, Canada

M. R. Turetsky

University of Guelph, Guelph, ON, Canada

K. P. Wickland

U.S. Geological Survey, Boulder, CO, USA

C. J. Wilson

Los Alamos National Laboratory, Los Alamos, NM, USA

S. A. Zimov

North-East Scientific Station, Cherskii, Siberia 
surface soils and permafrost, thus increasing microbial activity (Chambers and Chapin 2002; Yoshikawa et al. 2002; Grosse et al. 2011). Given the right set of dry conditions or changes in surface hydrology, thawing and fires could act together to expose and transfer permafrost $\mathrm{C}$ to the atmosphere very rapidly, especially in ecosystems with organic surface soils (McGuire et al. 2010). Together these biotic and abiotic factors will be some important determinants of the overall feedback from permafrost $\mathrm{C}$ to climate.

Questions concerning permafrost $\mathrm{C}$ release are easily framed but challenging to answer. Projections of change in permafrost and soil $\mathrm{C}$ remain limited by the range of mechanisms conceptualized within current models and by the scarcity of actual measurements from these remote landscapes. For example, future permafrost temperature is modeled over large scales as one-dimensional warming of the soil and ground material in response to increased air temperatures (Romanovsky and Osterkamp 2000). This propagated warming then increases microbial activity and $\mathrm{C}$ release. But in ice-rich permafrost, abrupt thaw processes that cause ice wedges to melt and the ground surface to collapse irreversibly appear to be driven by three-dimensional heat and water redistribution across the landscape (Osterkamp et al. 2009; Shur and Jorgenson 2007). Internal feedback dynamics accelerate the degradation of frozen ground beyond what is driven by temperature alone, and evidence for this type of rapid thaw that can expose deep C is already widespread (Jorgenson et al. 2006; Sannel and Kuhry 2011) and likely to increase. Also, simple biogeochemistry modules that describe the biological exchange of $\mathrm{C}$ between ecosystems and the atmosphere do not necessarily describe soil development processes that have led to the accumulation of large permafrost $\mathrm{C}$ pools in the first place (Koven et al. 2009). Models that do not accurately set initial conditions are not likely to make credible projections of permafrost $\mathrm{C}$ release under future conditions. Model development has been slowed by the difficulty in describing complex, nonlinear threshold processes and also because the field and lab measurements needed for parameterization are difficult to obtain from these extreme environments. The few field studies that exist show that temperature interacts with permafrost thaw, ground subsidence, and changes in surface hydrology to control $\mathrm{C}$ emissions from ecosystems, and that these factors are likely to differ across moisture/waterlogging thresholds in upland and lowland environments (Vogel et al. 2009; Schuur et al. 2009; Turetsky et al. 2011; Wickland et al. 2006).

Most terrestrial models used to assess the exchange of carbon between the biosphere and the atmosphere have incomplete or no representation of permafrost $\mathrm{C}$ dynamics. However, expert knowledge on permafrost $\mathrm{C}$ dynamics is more advanced than the information that has been incorporated into models. This then presents an opportunity to draw on other approaches in order to frame the scientific understanding of this issue (e.g., Lenton et al. 2008). Here we used a survey to quantify and evaluate variability among experts concerning our hypotheses of future permafrost $\mathrm{C}$ emissions to the atmosphere. We asked a group of international experts to provide quantitative estimates of permafrost change in response to four scenarios of warming. This expert survey helps outline the potential risk to society caused by permafrost thaw, and presents hypotheses about the magnitude of change in permafrost and $\mathrm{C}$ by the mechanism of climate warming and associated disturbances that will be then tested by new data collection and model development. Ultimately, the issues discussed here will need testing with improved quantitative models and to be compared with other important land and ocean system changes such as increases in plant biomass (greening) and the influence of declining ice/snow cover on albedo, which either offset or contribute to the climate feedback from a warming Arctic. 


\section{Methods}

The survey used to collect expert assessment of the vulnerability of permafrost $\mathrm{C}$ was divided into three questions (Appendix 1). Experts were asked to provide quantitative estimates of surface permafrost degradation (Q1), permafrost carbon release (Q2), and methane emissions (Q3) for three time periods: 1) by the year 2040 where modeled Arctic temperature increases ranged from $1.5-2.5{ }^{\circ} \mathrm{C}$ higher than the $1985-2004$ average baseline, 2) by the year 2100 where temperature increases ranged from 2.0 $7.5{ }^{\circ} \mathrm{C}$ higher, and 3) by the year 2300 where it was assumed temperature increases reached by 2100 remained at that level. The warming scenarios span possible atmospheric trajectories including one scenario of steadily increasing greenhouse gases, two scenarios of greenhouse gas stabilization after 2100, and one scenario of greenhouse gas stabilization then decline before 2100. Experts also provided self-reported expertise for each of the three questions and confidence ratings for each of the warming scenarios within each particular question. Survey results were obtained from a group of experts, selected from the larger scientific community because of their particular expertise and previous work on this topic, who attended a three-day workshop in June 2011 in Seattle, WA, USA, as part of the Vulnerability of Permafrost Carbon Research Coordination Network (RCN) (Appendix 2).

For each response we also calculated $\mathrm{C}$ emissions in $\mathrm{CO}_{2}$ equivalent (units of $\mathrm{Pg} \mathrm{C}$ ) by subtracting $\mathrm{CH}_{4}$ emission (Q3) from total $\mathrm{C}$ emission (Q2), multiplying $\mathrm{CH}_{4}$ by its 100 -year or 20-year global warming potential (GWP) of 33 and 105 respectively while also accounting for the mass difference between $\mathrm{CO}_{2}$ and $\mathrm{CH}_{4}$ gas, and adding that value back to total $\mathrm{C}$ emission (Shindell et al. 2009). Both the 100-year and 20-year GWP are relevant to warming by 2100 because some $\mathrm{CH}_{4}$ is released earlier in the century and some is released late, with its effect on climate relative to $\mathrm{CO}_{2}$ dependent on that timing. We recognize that calculations using GWP are an incomplete representation of the influence of permafrost $\mathrm{C}$ emissions on radiative forcing, but using this common unit allows for the influence of $\mathrm{CH}_{4}$ and $\mathrm{CO}_{2}$ emissions to be more directly compared because it accounts for the higher radiative forcing of $\mathrm{CH}_{4}$. For the numbers reported in the text, responses with a self-rated expertise of 1 (little or no expertise) were excluded. This removed any answers provided by experts that judged themselves to be at the lowest end of the expertise scale for any particular question. We analyzed the effect of this data screening by comparing the statistical distribution of responses of the final dataset to unscreened data (all respondents), as well as to a dataset that used only answers from the upper half of the expertise scale (expertise $\geq 3$ included). While this screening process did not end up having an overall directional effect on the mean or median response of the group for any particular question, it addressed imperfections in the expert selection process and considered the comfort level of individual experts in providing such an assessment.

Across much of the final dataset, the distribution of values was right-skewed such that mean responses across the dataset are larger in all cases than median values. We used natural log transformations of the raw data to achieve normal distributions. All lntransformed distributions were normally distributed at $p>0.05$ unless otherwise noted. Means, standard errors, and $95 \%$ confidence interval values were calculated for these ln-transformed distributions. In the text, values were then back-transformed so that they could be reported in actual units, with ranges representing the $95 \%$ confidence interval. In four cases (of 36), the data were normally distributed and no transformation was necessary. 


\section{Results}

\subsection{Surface permafrost degradation}

Across the group with self-ranked expertise $>1$, experts projected that surface permafrost would degrade $9-16 \%(n=33)$ from the current total areal extent over the next three decades, $48-63 \%$ by 2100 , and $67-80 \%$ over the next several centuries under the highest warming scenario presented to the group (representative concentration pathway [RCP] 8.5) (Fig. 1a). These values are approximately three times greater than permafrost degradation projected under the lowest warming scenario (RCP 2.6), which were 3-7\%, 11-18\%, and $20-30 \%$ for the three time frames, respectively. For the two lower warming scenarios, the rate of permafrost degradation was predicted to remain stable through 2040 and 2100 (assuming a constant rate over each respective time frame) (Appendix 3, Table A1), corresponding to a relatively small change in warming between 2040 and 2100 in those scenarios (Appendix 1). For the two higher warming scenarios, the change in warming was relatively greater between 2040 and 2100 and corresponded to higher projected rates of permafrost degradation in the later part of the century compared to the period before 2040 . Rates after 2100 declined substantially but still resulted in significant additional permafrost degradation by 2300 . This highlights expert agreement in the lag in the response of permafrost to changes in air temperature, given that the provided scenarios included no additional warming after 2100 but permafrost was still equilibrating to new, higher temperatures.

Of the twelve time-by-scenario combinations of permafrost degradation considered by the group, two-thirds had right-skewed distributions, while the remaining third had normal distributions. This differed somewhat from the opinions of $\mathrm{C}$ release, which were all right skewed. Normally distributed responses occurred only in the two higher warming scenarios and only for the 2100 and 2300 time frames. Log normal distributions might be expected in lower warming scenarios and shorter time frames because zero change acted as a lower limit cutoff point.

\subsection{Carbon release}

Under the highest warming scenario the total projected magnitude of $\mathrm{CO}_{2}$-equivalent emissions from permafrost zone soils was $19-45 \mathrm{Pg} \mathrm{C}(n=27)$ by $2040,162-288 \mathrm{Pg} \mathrm{C}$ by 2100 , and 381-616 Pg C by 2300. When Arctic temperature increase is limited to $2{ }^{\circ} \mathrm{C}$ by 2100 (the lowest warming scenario considered by this group, $\mathrm{RCP} 2.6$ ), $\mathrm{CO}_{2}$-equivalent emissions of 6-17 Pg C $(n=27)$ were projected by $2040,41-80 \mathrm{Pg} \mathrm{C}$ by 2100 , and 119$200 \mathrm{Pg} \mathrm{C}$ by 2300 (Fig. 1b). These $\mathrm{C}$ emissions, although quite sizeable, are roughly onethird the high-warming scenario emissions. These values calculated with a 100 -year $\mathrm{CH}_{4}$ GWP underestimate warming that is expected to occur within this century. In comparison, the high warming scenario $\mathrm{CO}_{2}$-equivalent emissions using a 20 -year $\mathrm{CH}_{4} \mathrm{GWP}$ are 29$69 \mathrm{Pg} \mathrm{C}$ by $2040,250-463 \mathrm{Pg} \mathrm{C}$ by 2100 , and $572-1004 \mathrm{Pg} \mathrm{C}$ by 2300 , but this in turn is an overestimate. The calculation of actual warming by 2100 is beyond the scope of the data collected by this survey and may lie somewhere between these two, but serves to illustrate the influence of choice of time horizon on this metric.

Much of the actual $\mathrm{C}$ release by mass is expected to be in the form of $\mathrm{CO}_{2}$. In terms of total $\mathrm{C}$ mass (of both $\mathrm{CO}_{2}$ and $\mathrm{CH}_{4}$ ), experts estimated that $15-33 \mathrm{Pg} \mathrm{C}(n=27)$ could be released by 2040, reaching 120-195 Pg C by 2100, and 276-414 Pg C by 2300 under the high warming scenario (Fig. 1c). This net release by 2100 corresponds to a $7-11 \%$ decline 

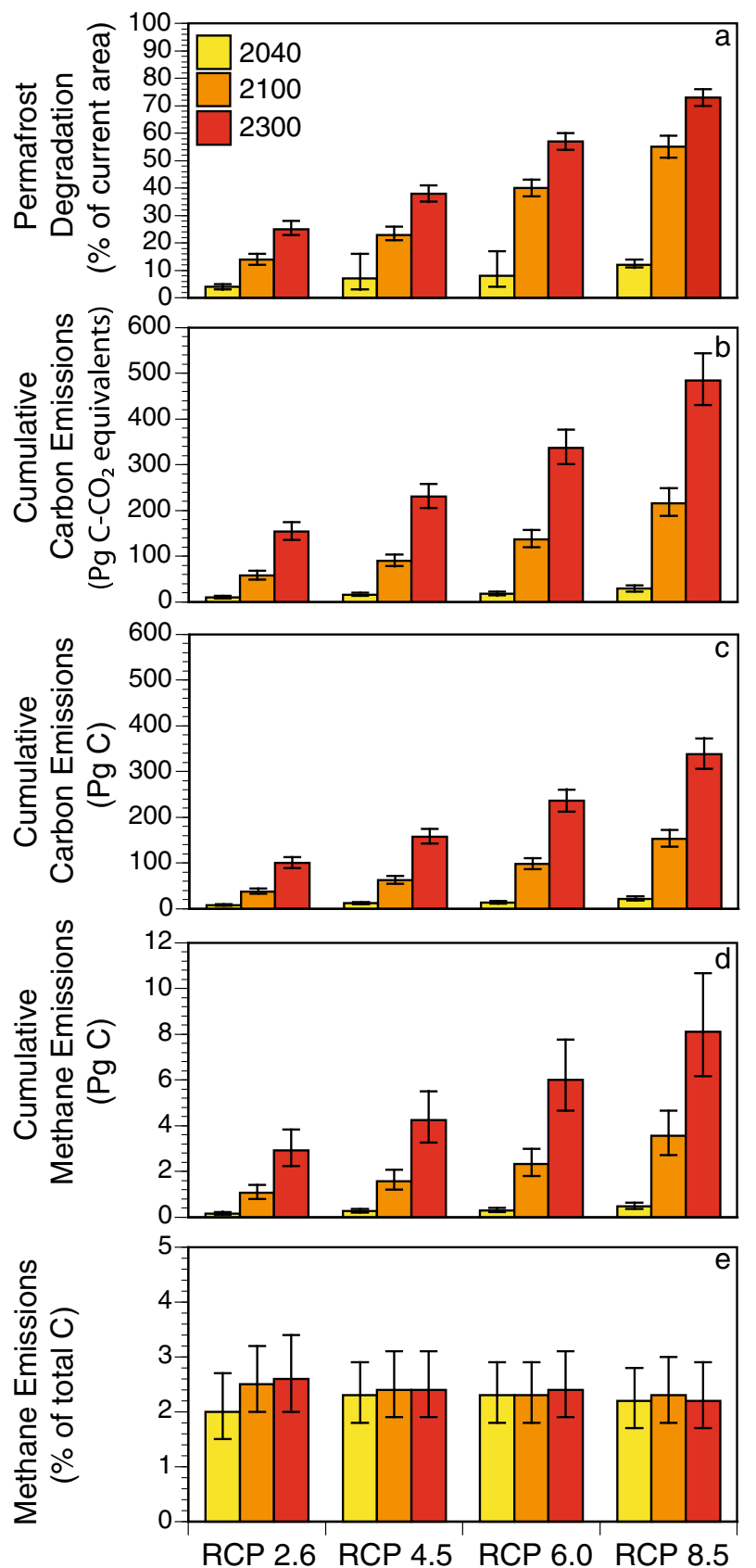

Fig. 1 Expert survey responses for cumulative a surface permafrost degradation, b carbon emissions ( $\mathrm{CO}_{2}$-equivalents using 100-year GWP), c carbon emissions (by mass), d methane emissions (by mass), and e relative methane emissions $(\%)$, over three time frame $(2040,2100,2300)$ in response to four IPCC global warming scenarios. Values are means and standard error 
in the $1700 \mathrm{Pg} \mathrm{C}$ pool currently contained in northern permafrost zone soils. Of that amount, only about $2.3 \%$ was expected to be in the form of $\mathrm{CH}_{4}$, corresponding to $0.26-0.85 \mathrm{Pg}$ $\mathrm{CH}_{4}-\mathrm{C}$ by $2040,2.03-6.21 \mathrm{Pg} \mathrm{CH}_{4}-\mathrm{C}$ by 2100 and 4.61-14.24 $\mathrm{Pg} \mathrm{CH}_{4}-\mathrm{C}$ by 2300 (Fig. 1d). The proportional release of $\mathrm{CH}_{4}$ estimated by experts was relatively invariant across all warming scenarios and time horizons (Fig. 1e). This two-order-of-magnitude difference in $\mathrm{CO}_{2}$ release relative to $\mathrm{CH}_{4}$ release incorporates the effects of both faster microbial decomposition in upland oxic environments compared to waterlogged anoxic environments, and the spatial distribution of these environments across the permafrost zone. However, the higher GWP of $\mathrm{CH}_{4}$ means that roughly one-third (100-year GWP) to one-half (20-year GWP) of the effect of future permafrost-zone $\mathrm{C}$ emissions on climate forcing, when calculated in this metric of $\mathrm{CO}_{2}$-equivalent, was expected to be a result of $\mathrm{CH}_{4}$ emissions from wetlands, lakes, and other oxygen-limited environments where organic matter will be decomposing.

Similar to estimates for permafrost area in some scenarios, initial $\mathrm{C}$ emission rates in the present to 2040 period were then projected to increase in the latter part of the century (assuming a constant rate over a given time frame); this increase was consistent across warming scenarios (Appendix 3, Table A1). Rates after 2100 were projected to decline but still were higher than present-2040 rates. As with permafrost degradation, the hypothesis of sustained 2100-2300 release resulted in substantial C emissions, even though there was no additional warming after 2100 in these scenarios. The source of these emissions from different geographical regions changed through time, even as cumulative emissions kept rising. By 2040, relatively more emissions were expected from the combined sporadic and discontinuous permafrost zones farther to the south as compared to the continuous permafrost zone even though the continuous zone is two times larger in land area (Fig. 2). By 2100 , relative emissions from the combined sporadic and discontinuous zones was expected to be roughly equal to those from the continuous zone, but by 2300 continuous-zone emissions were expected to be double that of the other zones. This predicted geographical shift in $\mathrm{C}$ emissions is consistent with the fact that permafrost in the sporadic and discontinuous zones is already closer to the thawing point, whereas continuous permafrost is colder. The more rapid response in the discontinuous and sporadic zones may then lead to lower emission rates after 2100 as a portion of the vulnerable soil $\mathrm{C}$ pool may have already been decomposed.

\subsection{Expertise and confidence}

The distribution of responses for both total $\mathrm{C}$ and $\mathrm{CH}_{4}$ emissions had right-skewed distributions for all scenarios and time frames. Again, because the group estimated $\mathrm{C}$ emissions at the lower end of the full possible range $(0-1700 \mathrm{Pg} \mathrm{C})$, zero change acted as a lower limit cutoff point. There were a small number of experts that thought $\mathrm{C}$ emissions could be significantly higher than the mean response of all experts; this pattern was consistent across scenarios and time frames.

As a group, the experts rated themselves as having a mean expertise of 2.4, 2.6, and 2.1 for permafrost degradation (Q1), total $\mathrm{C}$ emissions (Q2), and $\mathrm{CH}_{4}$ emissions (Q3) respectively on a scale from 1 (low) to 4 (high). For Q1 and Q2, self-ratings of 2 or 3 were most common (Appendix 3, Figure A1a). This pattern differed for Q3, which was dominated by ratings of 2 and had fewer $3 \mathrm{~s}$ than $1 \mathrm{~s}$. Confidence values were reported by warming scenario individually within each given question so there were four times as many total 

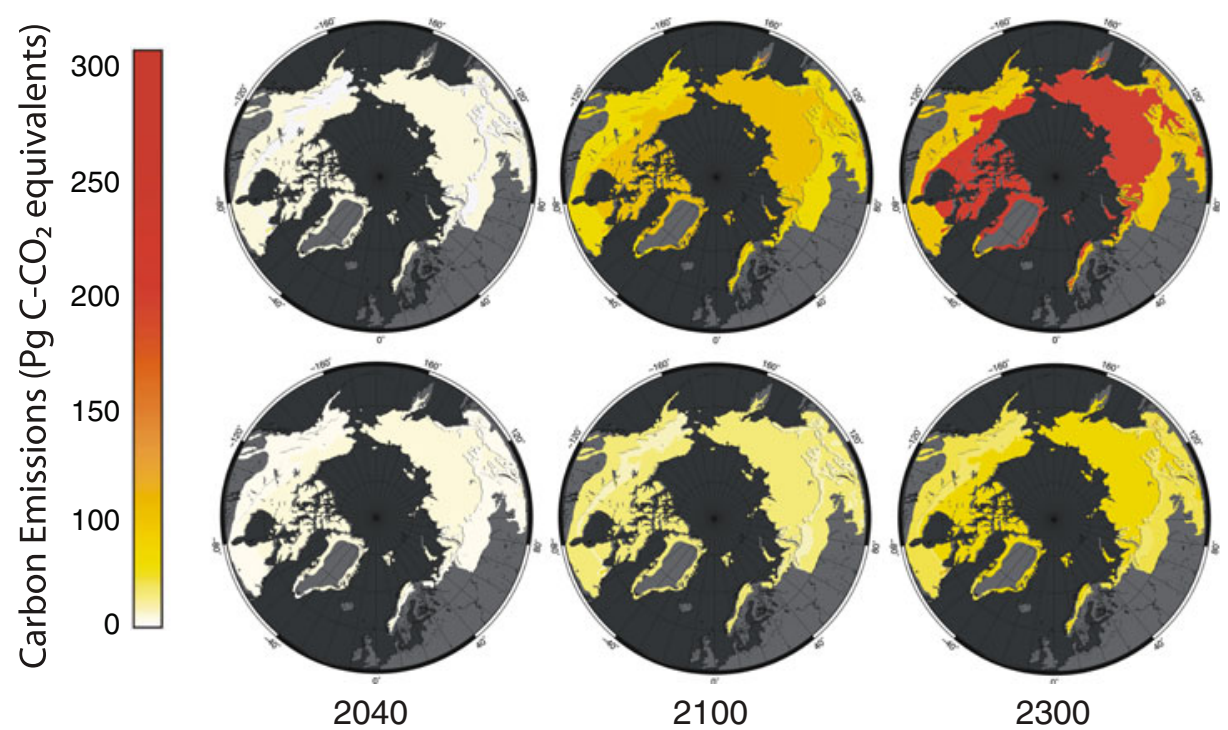

Fig. 2 Cumulative carbon emissions projected by experts as a result of warming climate for three different time horizons. Top figures represent a higher warming trajectory $\left(2.5^{\circ} \mathrm{C}\right.$ at $2040,7.5^{\circ} \mathrm{C}$ at $2100,7.5^{\circ} \mathrm{C}$ at $2300)$, and bottom figures represent a lower warming trajectory $\left(1.54{ }^{\circ} \mathrm{C}\right.$ at $2040,2.0{ }^{\circ} \mathrm{C}$ at $2100,2.0^{\circ} \mathrm{C}$ at 2300). Values are $\mathrm{Pg} \mathrm{C}\left(\mathrm{CO}_{2}\right.$ plus $\left.\mathrm{CH}_{4}\right)$ expressed on a common scale as $\mathrm{CO}_{2}$-equivalents (using 100 -year GWP) and are shown as median values (to account estimates of zero flux) for the continuous, the discontinuous, and the sporadic plus isolated permafrost zones

ratings. Mean confidence for Q1 was 2.1, Q2 was 1.9, and Q3 was 1.6. The most common confidence rating was 2 , followed by 1 , with the distribution of confidence also decreasing across the three questions (Appendix 3, Figure A1b). Confidence did not vary across the four warming scenarios for Q1, indicating that experts were equally confident of their low- and high-warming estimates of permafrost degradation (Appendix 3, Figure A1c). However, for Q2 and Q3, average confidence decreased slightly for each progressively warmer scenario (Pearson's, Q2 $r=-0.18$, Q3 $r=-0.19 p<0.05$ ). Across all questions and scenarios, confidence was positively correlated with expertise (Pearson's, $r=0.57, p<0.0001$ ), showing the overall link between these two metrics.

To examine the influence of self-rated expertise values on the distribution and magnitude of responses we compared survey results from the full group of respondents with those from expertise values greater than 1, and those with expertise values 3 and greater. All of these groupings showed the same right-skewed distribution with a small number of experts projecting substantially higher $\mathrm{C}$ emissions, and zero acting as a lower limit cutoff. There was little change in mean values across expertise groups (Appendix 3, Figure A2), with a small effect of increased sample size somewhat reducing the standard error of the estimate. This analysis is presented for total $\mathrm{C}$ emissions but the same pattern was observed for all questions.

\section{Discussion}

Perception of the importance of the permafrost $\mathrm{C}$ feedback to climate change has been dominated by the improved quantification of the large size of the permafrost soil $\mathrm{C}$ pool. But 
the potential climate feedback of this $\mathrm{C}$ pool is determined by three factors: how much is vulnerable to release, how fast will it be released, and in what form $\left(\mathrm{CO}_{2}\right.$ and $\left.\mathrm{CH}_{4}\right)$ will the release occur? At present there is a paucity of studies that provide comprehensive answers to these questions. The survey conducted here illustrates that experts in this field hypothesize significant $\mathrm{C}$ releases from permafrost zone soils over policy-relevant time horizons, and also hypothesize important lags whereby permafrost degradation and $\mathrm{C}$ emissions are expected to continue for decades and centuries even if average global temperature is stabilized. This exercise highlights both the potential risk from permafrost thaw, as well as the utility of expert elicitation in informing policy-relevant questions at the boundaries of our scientific understanding. Expert elicitation is a common methodology that has been used to define uncertainty in many scientific disciplines including the Earth sciences (Halpern et al. 2008; Lenton et al. 2008; Morgan et al. 2001; Aspinall 2010), and is a powerful tool allowing the integration of individual and community knowledge to help outline difficult questions. Our experience suggests that this process was a useful way to frame hypotheses about what the future might look like, as well as to gauge variability in hypotheses among scientists. We learned that significant time and energy was necessary to develop and revise the survey to ensure adequate specificity in question wording and format. And, the workshop proved critical for ensuring that experts understood seemingly straightforward questions in the same way.

Two general patterns about the scientific community opinion emerged from this process. First, the responses for many of the questions had right-skewed distributions. This was a consequence of the fact that, as a whole, the group viewed the vulnerable portion of the permafrost $\mathrm{C}$ pool to be only a fraction of the total pool (7-11\%, 95\% confidence interval) under the time frames and warming scenarios considered here, such that zero acted as a lower cutoff point. At the same time a small number of experts thought that considerably higher losses were possible, extending the upper tail of the distribution. The only deviation from this general pattern was observed in the responses for permafrost degradation in higher warming scenarios and longer time frames. Here, the larger magnitude of loss ( > $>50 \%)$ hypothesized by experts moved away from the lower limit cutoff such that the responses in those cases were more uniformly distributed. Interestingly, the distribution shape and magnitude of response did not differ when experts were screened by self-rated expertise. Even experts classified in the upper half of the expertise scale had a similar log normal distribution and confidence interval as the full group. For the full group, as well as within subsets of higher expertise respondents, most opinions were relatively clustered whereas some individuals thought the effects of warming could be substantially larger. This lack of difference between expertise levels emphasizes that scientific uncertainty on this issue is real and not just an artifact due to varying levels of experience with the subject matter. The initial workshop screening process, which selected leading scientists knowledgeable in some aspect of permafrost research, also likely contributed to removing some of the uncertainty that would have been present if surveying a more general group of scientists. The scientists that participated here are considered expert in this field as compared to scientists in general, or to earth system and climate scientists more specifically. It is important to recognize that the collective estimate set forth by the survey responses from this group is not the only possible set of hypotheses about the future feedback to climate from permafrost C. While this activity lays important new groundwork in the form of a testable hypothesis, it cannot rule out alternative hypotheses.

While it is important to put this expert estimate in the context of published work using different methods, direct comparisons are difficult because the topic is relatively new. Modeling work has been underway recently, but these projections each are derived without 
some of the important mechanisms discussed in this paper. The expert prediction of total $\mathrm{C}$ release by 2100 under the high warming scenario presented here is still 1.7-5.2 times larger than several recent modeling predictions with comparable climate scenarios (Schaefer et al. 2011; Koven et al. 2011; Schneider von Deimling et al. 2011). By 2300, model estimates of C emissions (190 $\pm 64 \mathrm{Pg} \mathrm{C}$ to 600-1000 Pg C) bracket the expert opinion (276-414 Pg C, $95 \%$ confidence interval), though noting that warming for model scenarios continued to increase between 2100 and 2300 but not in the question posed to the experts. Rapid C losses by 2100 projected by the experts likely reflect, in part, the perceived importance of abrupt thaw processes that are lacking within current models, as well as heightened awareness of the deep $\mathrm{C}$ pools. These areas, as well as others, are the subject of active model development for future permafrost $\mathrm{C}$ projections.

There are no comprehensive direct measurements of soil $\mathrm{C}$ loss from the permafrost zone at large scales. This is in part due to a scarcity of soil $\mathrm{C}$ measurement relative to other regions of the world, in combination with an overall difficulty of detecting changes in soil $\mathrm{C}$ pools due to large within-site soil heterogeneity. We do know the expected $7-11 \%$ decrease in the permafrost $C$ pool size by 2100 is comparable to the $7-14 \%$ decrease measured over 1 to 2 decades in landscape soil $\mathrm{C}$ inventories in England and Wales possibly as a result of climate change (Bellamy et al. 2005). While this comparison is of two very different regions, it demonstrates that a similar magnitude of soil $\mathrm{C}$ loss is possible at a regional scale. However, the time frame for permafrost zone soil $\mathrm{C}$ loss was estimated by experts to be roughly 6 times slower than measured rates of loss in England and Wales, since this magnitude of loss was expected to occur by 2100 . This difference in rate of loss is consistent with environmental differences between the two regions. Soil temperatures remain moderate for potential year round soil C loss in England and Wales, whereas the majority of permafrost soil C losses will be restricted to the short summer months, even with future warming. Because there is no broad set of historical measurements of permafrost $\mathrm{C}$ pools, it will be difficult to detect even major permafrost $\mathrm{C}$ losses directly without an extensive network of repeated measurements.

The magnitude of loss projected by experts agrees with a flux-based estimate from a permafrost ecosystem in Alaska where it was estimated that $5 \%$ of the permafrost $\mathrm{C}$ pool could be lost over a century with widespread permafrost degradation (Schuur et al. 2009). Because flux measurements integrated the response of both increased plant $\mathrm{C}$ uptake and net soil $\mathrm{C}$ loss due to permafrost degradation, offsets by plant biomass might explain why the loss result is on the lower end of the range found in the survey that considered only net soil loss. While only based on a single site, this field-based estimate agrees generally that only a fraction of the permafrost $\mathrm{C}$ pool is likely to be vulnerable by 2100 . Of course, even a fraction of this very large pool has important implications, especially considering the combined impact of $\mathrm{CO}_{2}$ and $\mathrm{CH}_{4}$ emissions. The expert projection of $\mathrm{CH}_{4}$ emitted by 2300 is consistent in magnitude with the tens of $\mathrm{Pg}$ thought to have come from northern ecosystems after the end of the last glacial period (Fischer et al. 2008). That historic release is known to be biogenic in origin emitted from wetlands, lakes, and other oxygen-limited environments, with some proportion likely bubbling out of thaw lakes forming in permafrost as the climate warmed to present-day conditions (Walter et al. 2007).

Because permafrost zone $\mathrm{C}$ release increases the cumulative impact of anthropogenic emissions, knowing the amount of permafrost $\mathrm{C}$ that will be released this century and beyond is a critical consideration when identifying climate change mitigation goals. Even given the real uncertainty that exists, this study highlights that experts hypothesize that the release of $\mathrm{C}$ from permafrost zone soils is likely to influence the pace of climate change in this century and beyond. Hypothesized permafrost $\mathrm{C}$ release by 2100 under a high warming scenario may be of similar magnitude to other biogenic $\mathrm{C}$ sources such as tropical 
deforestation, if current rates of that activity estimated at $1.1 \mathrm{Pg}$ C/year (2000-2010 average) were to continue (Peters et al. 2012). While these biogenic $\mathrm{C}$ sources are very different, the fact that $\mathrm{CH}_{4}$ makes up a substantial portion of permafrost $\mathrm{C}$ release means its overall radiative-forcing impact on climate could be more than two times larger than that from deforestation. Even so, these hypothesized emissions are unlikely to overshadow the impact of fossil fuel burning, which will continue to be the main source of $\mathrm{C}$ emissions and climate forcing under any scenario considered by this group. Permafrost $\mathrm{C}$ release in 100-year $\mathrm{CO}_{2}$ equivalent under the high warming scenario are equivalent to $8-18 \%$ (range based on expert confidence interval) of fossil fuel rates of $7.9 \mathrm{Pg} \mathrm{C} /$ year (2000-2010 average) projected out to 2040, or 22$40 \%$ of current fossil fuel rates projected out to 2100 . Of course, actual percentages will differ in the future as future fossil fuel emissions change through time. Under the lowest warming scenario, the percentages would only be one third of these values.

Because of the continued dominance of fossil fuel emissions, permafrost $\mathrm{C}$ release, if at a scale hypothesized here, is more likely to act as an important accelerator of climate change rather than a tipping point mechanism. In this way, permafrost $\mathrm{C}$ emissions on top of rapidly growing fossil fuel emissions would make temperature targets significantly harder to achieve than currently assessed by the IPCC. However, permafrost C release differs qualitatively from fossil fuel and deforestation emissions in that it occurs in remote places far from direct human influence. This not only makes these potential emissions difficult to observe and quantify, but also difficult to address through legislative or geoengineering solutions. One mitigation strategy might be to focus on limiting the overall magnitude of global temperature increase. The fact that the lowest warming scenario was hypothesized to avoid two thirds of the permafrost $\mathrm{C}$ release highlights the utility of a preventative approach. Many strategies for reducing fossil fuel and deforestation emissions to the atmosphere have been identified. The implementation of some of these strategies could have substantial benefits for permafrost $\mathrm{C}$ stability, keeping more of it frozen in the ground for longer thus reducing its impact on climate. It is important to reiterate that the high warming scenario is the trajectory of increasing greenhouse gas emissions that we are currently following, whereas the other scenarios require some restriction in atmospheric emissions over time.

This study focused on framing a hypothesis about permafrost soil $\mathrm{C}$ loss to the atmosphere, which has the potential to accelerate climate warming. But, as climate change occurs, other ecological and Earth system factors that affect $\mathrm{C}$ and energy exchange may act either to offset or augment some of the effects of $\mathrm{C}$ release from permafrost thaw. In the Arctic, increased plant biomass is likely to offset some of the $\mathrm{C}$ emissions from soil, driven both by warmer conditions and by nutrients released from decomposing organic matter (Walker et al. 2006). Based on steady-state vegetation and soil pools, it is likely that, over long time periods, emissions will still be significantly larger than uptake (Schuur et al. 2008), but uptake can have important implications especially for short-term dynamics (Schuur et al. 2009). Also, because nutrient release is inextricably linked to changes in permafrost soil C, it will also be important to understand other fates of nutrients aside from plant uptake. Microbial activity can release $\mathrm{N}_{2} \mathrm{O}$ (Elberling et al. 2010), which itself is a potent greenhouse gas with a GWP of 298 on a 100-year time scale (Meehl et al. 2007). Small releases of $\mathrm{N}_{2} \mathrm{O}$ could counterbalance the climate offset of $\mathrm{C}$ incorporated into plant biomass. A comprehensive review of these factors is beyond the scope of this survey, but testing the hypotheses presented here with improved models is important future work that will help place $\mathrm{C}$ emissions alongside estimates of plant uptake and the fate of other released elements to determine the overall potential climate feedback from permafrost $\mathrm{C}$. 
Acknowledgments Figure 2 was prepared by Reginald Muskett in the Permafrost Laboratory in the Geophysical Institute, UAF. Funding that supported the development of this paper was provided by National Science Foundation Vulnerability of Permafrost Carbon Research Coordination Network Grant \#955713.

Open Access This article is distributed under the terms of the Creative Commons Attribution License which permits any use, distribution, and reproduction in any medium, provided the original author(s) and the source are credited.

\section{References}

ACIA (2005) Arctic Climate Impacts Assessment. Cambridge University Press, Cambridge

Aspinall W (2010) A route to more tractable expert advice. Nature 463(7279):294-295. doi:10.1038/463294a

Bellamy PH, Loveland PJ, Bradley RI, Lark RM, Kirk GJD (2005) Carbon losses from all soils across England and Wales 1978-2003. Nature 437(7056):245-248. doi:10.1038/nature04038

Chambers SD, Chapin FS (2002) Fire effects on surface-atmosphere energy exchange in Alaskan black spruce ecosystems: implications for feedbacks to regional climate. J Geophys Res-Atmos 108(D1). doi:10.1029/ 2001jd000530

Dutta K, Schuur EAG, Neff JC, Zimov SA (2006) Potential carbon release from permafrost soils of Northeastern Siberia. Glob Change Biol 12(12):2336-2351. doi:10.1111/j.1365-2486.2006.01259.x

Elberling B, Christiansen HH, Hansen BU (2010) High nitrous oxide production from thawing permafrost. Nat Geosci 3(5):332-335. doi:10.1038/ngeo803

Euskirchen ES, McGuire AD, Kicklighter DW, Zhuang Q, Clein JS, Dargaville RJ, Dye DG, Kimball JS, McDonald KC, Melillo JM, Romanovsky VE, Smith NV (2006) Importance of recent shifts in soil thermal dynamics on growing season length, productivity, and carbon sequestration in terrestrial highlatitude ecosystems. Glob Change Biol 12(4):731-750. doi:10.1111/J.1365-2486.2006.01113.X

Fan ZS, Neff JC, Harden JW, Wickland KP (2008) Boreal soil carbon dynamics under a changing climate: a model inversion approach. J Geophys Res-Biogeo 113. doi:10.1029/2008JG000723

Fischer H, Behrens M, Bock M, Richter U, Schmitt J, Loulergue L, Chappellaz J, Spahni R, Blunier T, Leuenberger M, Stocker TF (2008) Changing boreal methane sources and constant biomass burning during the last termination. Nature 452(7189):864-867. doi:10.1038/Nature06825

Gorham E (1991) Northern Peatlands-Role in the carbon-cycle and probable responses to climatic warming. Ecol Appl 1(2):182-195. doi:10.2307/1941811

Grosse G, Harden J, Turetsky M, McGuire AD, Camill P, Tarnocai C, Frolking S, Schuur EAG, Jorgenson T, Marchenko S, Romanovsky V, Wickland KP, French N, Waldrop M, Bourgeau-Chavez L, Striegl RG (2011) Vulnerability of high-latitude soil organic carbon in North America to disturbance. J Geophys ResBiogeo 116. doi:10.1029/2010jg001507

Halpern BS, Walbridge S, Selkoe KA, Kappel CV, Micheli F, D’Agrosa C, Bruno JF, Casey KS, Ebert C, Fox HE, Fujita R, Heinemann D, Lenihan HS, Madin EMP, Perry MT, Selig ER, Spalding M, Steneck R, Watson R (2008) A global map of human impact on marine ecosystems. Science 319(5865):948-952. doi:10.1126/science. 1149345

Jobbagy EG, Jackson RB (2000) The vertical distribution of soil organic carbon and its relation to climate and vegetation. Ecol Appl 10(2):423-436. doi:10.2307/2641104

Johnson KD, Harden J, McGuire AD, Bliss NB, Bockheim JG, Clark M, Nettleton-Hollingsworth T, Jorgenson MT, Kane ES, Mack M, O’Donnell J, Ping CL, Schuur EAG, Turetsky MR, Valentine DW (2011) Soil carbon distribution in Alaska in relation to soil-forming factors. Geoderma 167-68:71-84. doi:10.1016/j.geoderma.2011.10.006

Jorgenson MT, Shur YL, Pullman ER (2006) Abrupt increase in permafrost degradation in Arctic Alaska. Geophysical Research Letters 33 (2). doi:10.1029/2005g1024960

Kanevskiy M, Shur Y, Fortier D, Jorgenson MT, Stephani E (2011) Cryostratigraphy of late Pleistocene syngenetic permafrost (yedoma) in northern Alaska, Itkillik River exposure. Quaternary Res 75(3):584596. doi:10.1016/j.yqres.2010.12.003

Koven C, Friedlingstein P, Ciais P, Khvorostyanov D, Krinner G, Tarnocai C (2009) On the formation of highlatitude soil carbon stocks: Effects of cryoturbation and insulation by organic matter in a land surface model. Geophysical Research Letters 36:-. doi:10.1029/2009g1040150

Koven CD, Ringeval B, Friedlingstein P, Ciais P, Cadule P, Khvorostyanov D, Krinner G, Tarnocai C (2011) Permafrost carbon-climate feedbacks accelerate global warming. P Natl Acad Sci U S A 108(36):1476914774. doi:10.1073/pnas. 1103910108 
Lawrence DM, Slater AG, Swenson SC (2011) Simulation of Present-day and Future Permafrost and Seasonally Frozen Ground Conditions in CCSM4. J Clim. doi:10.1175/jcli-d-11-00334.1

Lenton TM, Held H, Kriegler E, Hall JW, Lucht W, Rahmstorf S, Schellnhuber HJ (2008) Tipping elements in the Earth's climate system. P Natl Acad Sci U S A 105(6):1786-1793. doi:10.1073/ pnas.0705414105

Mack MC, Bret-Harte MS, Hollingsworth TN, Jandt RR, Schuur EAG, Shaver GR, Verbyla DL (2011) Carbon loss from an unprecedented Arctic tundra wildfire. Nature 475(7357):489-492. doi:10.1038/ nature 10283

McGuire AD, Macdonald RW, Schuur EAG, Harden JW, Kuhry P, Hayes DJ, Christensen TR, Heimann M (2010) The carbon budget of the northern cryosphere region. Curr Opin Environ Sustain 2(4):231-236. doi:10.1016/j.cosust.2010.05.003

Meehl GA, Stocker TF, Collins WD, Friedlingstein P, Gaye AT, Gregory JM, Kitoh A, Knutti R, Murphy JM, Noda A, Raper SCB, Watterson IG, Weaver AJ, Zhao Z-C (2007) Global Climate Projections. In: Solomon S, Qin D, Manning M, Chen Z, Marquis M, Averyt KB, Tignor M, Miller HL (eds) Climate Change 2007: The Physical Science Basis. Contribution of Working Group I to the Fourth Assessment Report of the Intergovernmental Panel on Climate Change. Cambridge University Press, Cambridge, United Kingdom and New York, NY, USA

Morgan MG, Pitelka LF, Shevliakova E (2001) Elicitation of expert judgments of climate change impacts on forest ecosystems. Clim Chang 49:279-307. doi:10.1023/a:1010651300697

Osterkamp TE, Jorgenson MT, Schuur EAG, Shur YL, Kanevskiy MZ, Vogel JG, Tumskoy VE (2009) Physical and ecological changes associated with warming permafrost and thermokarst in interior Alaska. Permafr Periglac Process 20(3):235-256. doi:10.1002/ppp.656

Peters GP, Marland G, Le Quere C, Boden T, Canadell JG, Raupach MR (2012) Rapid growth in CO2 emissions after the 2008-2009 global financial crisis. Nature Clim Change 2:2-4. doi:10.1038/nclimate1332

Ping CL, Michaelson GJ, Kane ES, Packee EC, Stiles CA, Swanson DK, Zaman ND (2010) Carbon stores and biogeochemical properties of soils under black spruce forest, Alaska. Soil Sci Soc Am J 74(3):969-978. doi:10.2136/sssaj2009.0152

Romanovsky VE, Osterkamp TE (2000) Effects of unfrozen water on heat and mass transport processes in the active layer and permafrost. Permafr Periglac Process 11(3):219-239. doi:10.1002/1099-1530(200007/ 09) $11: 3<219::$ aid-ppp352>3.0.co;2-7

Romanovsky VE, Smith SL, Christiansen HH, Shiklomanov NI, Drozdov DS, Oberman NG, Kholodov AL, Marchenko SS (2011) Permafrost [in Arctic Report Card 2011], http://www.arctic.noaa.gov/reportcard

Saito K, Kimoto M, Zhang T, Takata K, Emori S (2007) Evaluating a high-resolution climate model: Simulated hydrothermal regimes in frozen ground regions and their change under the global warming scenario. J Geophys Res-Earth Surf 112 (F2):-. doi:10.1029/2006jf000577

Sannel ABK, Kuhry P (2011) Warming-induced destabilization of peat plateau/thermokarst lake complexes. J Geophys Res-Biogeo 116. doi:10.1029/2010jg001635

Schaefer K, Zhang T, Bruhwiler L, Barrett AP (2011) Amount and timing of permafrost carbon release in response to climate warming. Tellus B:no-no. doi:10.1111/j.1600-0889.2011.00527.x

Schirrmeister, L., G. Grosse, S. Wetterich, P. P. Overduin, J. Strauss, E. A. G. Schuur, and H.-W. Hubberten (2011), Fossil organic matter characteristics in permafrost deposits of the northeast Siberian Arctic. J Geophys Res 116:G00M02. doi:10.1029/2011JG001647

Schneider von Deimling T, Meinshausen M, Levermann A, Huber V, Frieler K, Lawrence DM, Brovkin V (2011) Estimating the permafrost-carbon feedback on global warming. Biogeosciences 8:4727-4767

Schuur EAG, Bockheim J, Canadell JG, Euskirchen E, Field CB, Goryachkin SV, Hagemann S, Kuhry P, Lafleur PM, Lee H, Mazhitova G, Nelson FE, Rinke A, Romanovsky VE, Shiklomanov N, Tarnocai C, Venevsky S, Vogel JG, Zimov SA (2008) Vulnerability of permafrost carbon to climate change: implications for the global carbon cycle. Bioscience 58(8):701-714. doi:10.1641/B580807

Schuur EAG, Vogel JG, Crummer KG, Lee H, Sickman JO, Osterkamp TE (2009) The effect of permafrost thaw on old carbon release and net carbon exchange from tundra. Nature 459(7246):556-559. doi:10.1038/Nature08031

Shindell DT, Faluvegi G, Koch DM, Schmidt GA, Unger N, Bauer SE (2009) Improved attribution of climate forcing to emissions. Science 326(5953):716-718. doi:10.1126/science.1174760

Shur YL, Jorgenson MT (2007) Patterns of permafrost formation and degradation in relation to climate and ecosystems. Permafr Periglac Process 18(1):7-19. doi:10.1002/ppp.582

Tarnocai C, Canadell JG, Schuur EAG, Kuhry P, Mazhitova G, Zimov S (2009) Soil organic carbon pools in the northern circumpolar permafrost region. Global Biogeochemical Cycles 23:-. doi:10.1029/ 2008gb003327

Turetsky MR, Donahue WF, Benscoter BW (2011) Experimental drying intensifies burning and carbon losses in a northern peatland. Nature Communications 2. doi:10.1038/ncomms 1523 
Vogel J, Schuur EAG, Trucco C, Lee H (2009) Response of CO(2) exchange in a tussock tundra ecosystem to permafrost thaw and thermokarst development. J Geophys Res-Biogeo 114. doi:10.1029/2008jg000901

Walker MD, Wahren CH, Hollister RD, Henry GHR, Ahlquist LE, Alatalo JM, Bret-Harte MS, Calef MP, Callaghan TV, Carroll AB, Epstein HE, Jonsdottir IS, Klein JA, Magnusson B, Molau U, Oberbauer SF, Rewa SP, Robinson CH, Shaver GR, Suding KN, Thompson CC, Tolvanen A, Totland O, Turner PL, Tweedie CE, Webber PJ, Wookey PA (2006) Plant community responses to experimental warming across the tundra biome. P Natl Acad Sci U S A 103:1342-1346. doi:10.1073/pnas.0503198103

Walter KM, Edwards ME, Grosse G, Zimov SA, Chapin FS (2007) Thermokarst lakes as a source of atmospheric $\mathrm{CH}(4)$ during the last deglaciation. Science 318(5850):633-636. doi:10.1126/ science. 1142924

Wickland KP, Striegl RG, Neff JC, Sachs T (2006) Effects of permafrost melting on CO2 and CH4 exchange of a poorly drained black spruce lowland. J Geophys Res-Biogeo 111 (G2). doi:10.1029/2005jg000099

Yoshikawa K, Bolton WR, Romanovsky VE, Fukuda M, Hinzman LD (2002) Impacts of wildfire on the permafrost in the boreal forests of Interior Alaska. J Geophys Res-Atmos 108 (D1). doi:10.1029/ $2001 \mathrm{jd} 000438$

Zimov SA, Davydov SP, Zimova GM, Davydova AI, Schuur EAG, Dutta K, Chapin FS (2006) Permafrost carbon: Stock and decomposability of a globally significant carbon pool. Geophysical Research Letters 33 (20):-. doi:10.1029/2006g1027484 